\title{
Antibody Levels against Newcastle Disease Virus in Chickens in Rajshahi and Surrounding Districts of Bangladesh
}

\author{
K. M. Mozaffor Hossain \\ Department of Biological Science and Technology \\ Tokyo University of Science, 2641 Yamazaki, Noda-Shi \\ Chiba 278-8510, Japan \\ Tel: 81-4-7124-1501 ext.4425 E-mail: mozaffor03@yahoo.com \\ Md. Yamin Ali \\ Upazila Veterinary Hospital, Paba, Rajshahi, Bangladesh \\ Tel: 88-017-1611-3965_E-mail: yamin_dr@yahoo.com \\ Ichiro Yamato (Corresponding author) \\ Department of Biological Science and Technology \\ Tokyo University of Science, 2641 Yamazaki, Noda-Shi \\ Chiba 278-8510, Japan \\ Tel: 81-4-7124-1501 ext. 4405 E-mail: iyamato@rs.noda.tus.ac.jp
}

\begin{abstract}
A serological survey on the prevalence of antibodies against Newcastle disease virus was carried out in broiler and layer chickens in Rajshahi and surrounding districts of Bangladesh. A total of 960 serum samples were collected from broiler (102) and layer (90) farms from January to December 2008. Haemagglutination inhibition (HI) test was performed using Newcastle disease virus antigen to determine antibody titers against Newcastle disease virus. The overall seroprevalence of antibodies against Newcastle disease virus in broiler and layer chickens were 78.04\% (510 samples) and 96.67\% (450 samples), respectively. Antibody levels against Newcastle disease virus were recorded for different age groups of broiler and layer chickens. Seroprevalence of antibodies against Newcastle disease virus was found significantly $(\mathrm{p}<0.05)$ higher in young (broiler $23.88 \%$, layer $11.33 \%$ ) than in adults (broiler $18.38 \%$, layer $9.22 \%$ ). Furthermore, these levels were recorded for different seasons of the year, with significantly $(\mathrm{p}<0.05)$ higher during summer in comparison to other seasons.
\end{abstract}

Keywords: Chicken, Haemagglutination inhibition (HI) test, Newcastle disease virus, Serum antibody

\section{Introduction}

Newcastle disease (ND) also known as Ranikhet disease (RD) is a highly contagious viral disease that attacks many species of domestic and wild birds (Al-Garib et al., 2003). The causal agent is the Newcastle disease virus (NDV) which is a negative-sense single-stranded RNA virus belonging to the family Paramyxoviridae. Through restriction site mapping and sequence analysis of the fusion gene (F-gene), NDV strains have been divided into eight genotypes (Ballagi et al., 1996). The strains are also classified into highly virulent (velogenic), intermediate (mesogenic) or avirulent (lentogenic) based on their pathogenicity in chickens (Beard and Hanson, 1984). ND is reported as the most important viral disease of poultry in the world including developing countries (Adene, 1990 and Spradbrow, 1997). In Africa and Asia ND is a major constraint against the development of both industrial and village poultry production (Alders et al., 2001). NDV infections of poultry range from latent to rapidly fatal depending upon the pathotype of virus involved (Alexander, 2003). The transmission of NDV occurs through newly introduced birds, selling or giving away sick birds, exposure to fecal and other excretions from infected birds and contact with contaminated feed, water, equipment and clothing (Tu et al., 1998). The disease causes high economic losses due to high mortality, morbidity, stress, decreased egg production and hatchability (Alexander, 2000). Vaccination has been reported as the only safeguard against endemic ND 
(Orajaka et al., 1999). The current vaccination schedule in Bangladesh directed by the Directorate of Livestock Services (DLS) includes administration of a live lentogenic vaccine (BCRDV) of F-strain by intra-ocular instillation to chicks followed by a live mesogenic vaccine (RDV) of M-strain by intramuscular injection at 21 days old chicks which is repeated at every six months interval. The infection still occurs in Bangladesh every year in the form of epidemic and appears to cause up to $40-60 \%$ of the total mortality in poultry population creating one of the major problems in the development of poultry industry in Bangladesh (Chowdhury et al., 1982). Chicks from immunized parents possess high level of maternally derived antibodies (MDA) which protect them against virulent and vaccine viruses (Allan et al., 1978 and Rahman et al., 2002). It was reported that MDA are protective (Allan et al., 1978) and neutralize vaccine virus if the chicks are vaccinated in the presence of high level of MDA (Awang et al., 1992). In order to formulate appropriate vaccination schedule and control measures the serological status of NDV among chickens need to be elucidated.

\section{Materials and methods}

This study was conducted jointly by Lab Avian laboratory, Rajshahi and Department of Animal Husbandry and Veterinary Science, University of Rajshahi, Bangladesh from January to December 2008. A total of one hundred and ninety two (broiler 102 and layer 90) poultry flocks were selected in Rajshahi and surrounding districts of Bangladesh. From each flock five chickens (a total of 960 chickens) were randomly selected for blood collection. Two $\mathrm{ml}$ of blood was collected aseptically from wing vein of each bird and allowed to clot. Then sera were separated and stored at $-20^{\circ} \mathrm{C}$ until the haemagglutination inhibition test was carried out. The antigen (Avinew ${ }^{\mathbb{B}} \mathrm{ND}, \mathrm{VG} / \mathrm{GA}$ strain) used in this study was purchased from the Advance Animal Science Co. Ltd. Dhaka, Bangladesh. HI test was performed to detect the antibodies against NDV.

\subsection{Preparation of chicken red blood cell (RBC) suspension}

A total of $5 \mathrm{ml}$ of chicken blood was collected aseptically in a disposable syringe containing $1 \mathrm{ml}$ of sodium citrate ( $4 \%$ solution) as anticoagulant. The blood was centrifuged at $1500 \mathrm{rpm}$ for 15 minutes and the plasma and buffy coat were removed with a pipette. After washing three times with phosphate buffered saline (PBS), $1 \%$ suspension in PBS was prepared for HI test.

\subsection{Haemagglutination inhibition (HI) test}

$\mathrm{HI}$ test was done according to the procedure of OIE (2002). Briefly, two fold serial dilution of $25 \mu 1$ serum was made with PBS in V-bottomed microtiter plates (Nunc) up to $10^{\text {th }}$ well. Twenty five $\mu 1$ of 4 haemagglutinating (HA) units of Newcastle disease virus or antigen was added up to $11^{\text {th }}$ well. The plates were kept at room temperature for more than 30 minutes to facilate antigen antibody reaction. Then $50 \mu 1$ of $1 \%(\mathrm{v} / \mathrm{v})$ chicken RBC suspension was added to each well. The $11^{\text {th }}$ well contains antigen and RBCs as the positive control and the $12^{\text {th }}$ well contains only RBCs as the negative control. After gentle mixing, the RBCs were allowed to settle at room temperature for 40 minutes and agglutination was assessed by tilting the plates. The samples showing peculiar central button shaped settling of RBCs were recorded as positive and maximum dilution of each sample causing haemagglutination inhibition was considered as the end point, which was used to estimate the HI titer. The HI titer of each serum sample was expressed as reciprocal of the serum dilution.

\subsection{Statistical analysis}

The seroprevalence of NDV infection in relation to age of birds and seasons of year was compared by means of the Chi-square test. A significant level of $5 \%$ was used.

\section{Results and discussion}

\subsection{Prevalence of antibodies against NDV in broiler chickens}

A total of 510 serum samples were collected from different commercial broiler farms and were subjected to HI test. Out of them, 398 were found positive for specific immunity against NDV with an overall positive percentage of 78.04 (Table 1); ND-HI titer of $\log 2^{3}$ and above is generally accepted as positive for specific immunity (Allan and Gough, 1974). Different age groups were examined in detail. In 1-2 weeks of age HI antibody titers varied from $2^{1}$ to $2^{6}$ (their respective percentages were 8.90, 19.37, 11.52, 22.51, 30.89 and 6.81) with a geometric mean titer (GMT) of 12.78 but in 3-4 weeks of age HI antibody titers varied from $2^{2}$ to $2^{7}$ (their respective percentages were $14.53,18.02,38.95,20.93,6.40$ and 1.16) with a GMT of 7.47. Whereas in 5-6 weeks of age $\mathrm{HI}$ antibody titers varied from $2^{2}$ to $2^{8}$ (their respective percentages were 22.45, 33.33, 20.41, 11.56, 8.84, 2.04 and 1.36) with a GMT of 5.67. Similar reports have been described by Numan et al. (2005) who reported that $98.07 \%$ of serum samples were positive for specific immunity against NDV for broilers in Pakistan. This finding is also in agreement with previous report of Bell and Moulodi (1988) who recorded the antibody levels against NDV in different regions of Morocco ranging from 5 to $83 \%$ (average 35\%) of the chickens 
sampled. In the present study, the birds in 1-2 weeks of age showed the highest level of antibody titers (GMT 12.78) and showed relatively low susceptibility to clinical infection. The antibody titers in 1-2 weeks of age is higher may be due to high levels of MDA which are transmitted from hens to chicks and protect them at early ages. On the other hand, the birds within 3-4 weeks of age showed intermediary level of serum antibody titers (GMT 7.47). This level is unexpected, since we expected that through vaccination the level of serum antibody titers should increase at this age. Furthermore, the birds within 5-6 weeks of age showed low level of serum antibody titers (GMT 5.67) than the previous two groups and showed relatively high susceptibility to clinical infection. There are several possible reasons for these low levels of antibody titers in birds of old ages (3-6 weeks), such as poor quality of vaccine, unsuitable vaccination schedule, presence of immunosuppressive substances in the feed or immunosuppressive diseases.

\subsection{Prevalence of antibodies against NDV in layer chickens}

A total of 450 serum samples were collected from different commercial layer farms and were subjected to HI test. Among them, 435 were found positive for specific immunity against NDV with an overall positive percentage of 96.67 (Table 2). Different age groups of commercial layer chickens were also examined in detail. In 17-28, 29-40 and 41-52 weeks of age groups, HI antibody titers varied from $2^{2}$ to $2^{9}$ (their respective percentages were $4.90,6.86,8.82,9.80,23.53,20.59,24.51,0.98 ; 3.06,5.10,7.14,12.24,14.29,42.86,13.27,2.04$ and 3.45, 4.60, $6.90,9.20,24.14,26.44,22.99,2.30$ ) with GMTs of $33.11,37.13$ and 39.05 , respectively. Whereas in 53-64 and 65 -above weeks of age groups, HI antibody titers varied from $2^{2}$ to $2^{10}$ (their respective percentages were 2.41, $6.02,6.02,8.43,21.69,32.53,16.87,3.61,2.41$ and $2.50,5.00,3.75,6.25,32.50,23.75,18.75,3.75,3.75)$ with GMTs of 41.80 and 44.86, respectively. Similar reports have been described by Numan et al. (2005) who reported $100 \%$ of layer chickens were positive for specific immunity against NDV in Pakistan. This finding also supports the report of Ezeokoli et al. (1984) who recorded 72\% prevalence of antibodies against NDV in free range and $62.9 \%$ in traditionally managed backyard flocks in Nigeria. The low level of antibody titers $\left(<2^{3}\right)$ in some vaccinated layer birds $(5+3+3+2+2=15)$ in this study may be due to the poor vaccine quality or vaccine failure. There are several possible causes for the vaccine failure in the developing countries like poor manufacturing standards, lack of adequate storage facilities, application of expired vaccines, faulty application and vaccine handling during transportation (Vui et al., 2002). Heat stress and water deprivation in birds also lead to production of steroids and thus resultant immunosuppressant (Sil et al., 2002). Quality of water given to the birds is also questionable since it might hinder the development of specific immunity possibly due to acid base imbalance.

\subsection{Prevalence of antibodies against NDV in broiler and layer chickens in relation to seasons}

The distributions of NDV antibody titers of serum samples in different seasons for broiler and layer birds are shown in Table 3. The overall $90.00 \%, 64.35 \%, 79.39 \%$ and $75.81 \%$ broiler chickens had protective HI titers against NDV in summer (Mar-May), rainy (Jun-Aug), autumn (Sep-Nov) and winter (Dec-Feb), respectively. Whereas, $98.35 \%, 92.86 \%, 97.46 \%$ and $97.98 \%$ layer chickens had protective HI titers in the summer, rainy, autumn and winter, respectively. The protective HI titers were higher in summer season and lower in rainy season for both broiler and layer chickens. The HI titers obtained in the present study were higher than those reported by Biswas et al. (2006) who recorded that $64.0 \%, 47.4 \%, 62.6 \%$ and $56.3 \%$ of sonali chickens in southern part of Bangladesh had protective HI titers against NDV in the autumn, winter, summer and rainy seasons, respectively. The issue of the seasonal prevalence is controversial and may vary according to the environmental, nutritional and socioeconomic conditions, under which poultry is kept. Awan et al. (1994) reported that ND peaks during and at the end of the dry season; whereas, Nguyen (1992) reported that in Vietnam ND peaks generally at the beginning of the rainy season. Martin (1992) reported that ND outbreaks are associated with the change of seasons. In fact, several parameters should be evaluated for the implementation of a successful NDV vaccination program.

\section{References}

Adene, D. F. (1990). Country report on the management and health problems of rural poultry stock in Nigeria. In: Proceedings of Centre for Tropical Agriculture (pp. 175-182). Seminar on Smallholder Rural Poultry Production, Thessaloniki, Greece.

Alders, R. G., Costa, R., Dias, P., Fringe, R., Fumo, A., Lobo, Q., Mata, B. V., Silva, A., \& Young, M. P. (2001). Investigations into the Control of Newcastle Disease in Village Chickens in Mozambique: Review of work done in Mozambique. Report on the ACIAR/INIVE Newcastle Disease Control Project Coordination Meeting, Tofo, Inhambane Province, Appendix 3. 
Alexander, D. J. (2000). Newcastle disease and other avian Paramyxoviruses. In: Revue Scientifique et Technique de l'OIE, (pp. 443-462).

Alexander, D. J. (2003). Newcastle disease, other Parmyxoviruses and Pneumovirus Infections. In: Saif, Y. M., Barnes, H. J., Glossons, G. R., Fadly, M. A., McDougald, D. J., \& Swayne, D. E. (Eds.), Diseases of Poultry (pp. 63-100), Iowa State press, Ames.

Al-Garib, S. O., Gielkens, A. L. J., \& Koch, G. (2003). Review of Newcastle disease virus with particular references to immunity and vaccination. World's Poultry Science Journal, 59, 185-197.

Allan, W. H., \& Gough, R. E. (1974). A standard haemagglutination-inhibition test for Newcastle disease: A comparison of macro-and micromethods. Veterinary Record, 95, 120-123.

Allan, W. H., Lancaster, J. A., \& Toth, B. (1978). Newcastle disease vaccines: their production and use. FAO animal production and health series, No. 10, FAO, Rome.

Awan, M. A., Otte, M. J., \& James, A. D. (1994). The epidemiology of Newcastle disease in rural poultry. Avian Pathology, 23, 405-423.

Awang, I. P. R., Wan-Ahmad-Kusiry, W. S., \& Abdul Rasak, J. (1992). Detection of maternal antibody against Newcastle disease virus in chicks using an indirect immunoperoxidase test. Journal of Veterinary Malaysia, 4, 19-23.

Ballagi, P. A., \& Wehmann, E. (1996). Identification and grouping of Newcastle disease virus strains by Restriction site analysis of a region from the F gene. Arch Virol, 141, 243-261.

Beard, C. W., \& Hanson, R. P. (1984). Newcastle disease. In: Hofstad, M. S., Barnes, H. J., Calnek, B. W., Reid, W. M., \& Yoder, H. W. (Eds.), Diseases of Poultry (pp. 450-470), Iowa State University Press, Ames.

Bell, J. G., \& Moulodi, S. (1988). A reservoir of virulent Newcastle disease virus in village chicken flocks. Preventive Veterinary Medicine, 6, 37-42.

Biswas, P. K., Uddin, G. M. N., Barua, H., Roy, K., Biswas, D., Ahad, A., \& Debnath, N. C. (2006). Immune status of semi-scavenging Sonali chickens in Bangladesh against Newcastle disease. Livestock Rural Development, 18, 6 .

Chowdhury, S. I., Chowdhury, T., Sarker, A. J., Amin, M. M., \& Hossain, W. (1982). The role of residual maternal antibody on immune response and selection of an optimum age for primary vaccination of chicks. Studies on Newcastle disease in Bangladesh. A research report. 2 (pp. 12-22).

Ezeokoli, C. D., Umoh, J. U., Adesiyun, A. A., \& Abdu, P. (1984). Prevalence of Newcastle disease virus antibodies in local and exotic chicken under different management systems in Nigeria. Bulletin of Animal Health and Production in Africa, 32, 253-257.

Martin, P. A. J. (1992). The Epidemiology of Newcastle disease in village chickens. In: Newcastle disease in village chickens, control with thermostable oral vaccines (P. B. Spradbrow, Eds.), Proceeding No. 39 (pp. 40-45), Canberra: Australian Centre for International Agricultural Research (ACIAR).

Nguyen, T. D. (1992). Poultry Production and Newcastle disease in Vietnam. In: Newcastle disease in village chickens, control with thermostable oral vaccines (P. B. Spradbrow, Eds.), Proceeding No. 39 (pp. 169-170), Canberra: Australian Centre for International Agricultural Research (ACIAR).

Numan, M., Zahoor, M. A., Khan, H. A., \& Siddique, M. (2005). Serological status of Newcastle disease in broilers and layers in Faisalabad and surrounding districts. Pakistan Veterinary Journal, 25 (2), 55-58.

OIE. (2002). Office International Des Epizooties. Manual of Standards for Diagnostic Tests and Vaccines. $4^{\text {th }}$ Eds., Paris, France.

Orajaka, L. J. E., Adene, D. F., Anene, B. M., \& Onuoha, E. A. (1999). Seroprevalence of Newcastle disease in local chickens from Southeast derived savannah zone of Nigeria. Revue Elevage Mẻdecine Vétérinaire Pays Tropicaux, 52 (3-4), 185- 188.

Rahman, M. M., Bari, A. S. M., Giusuddin, M., Islam, M. R., Alam, J., \& Sil, G. C. (2002). Evaluation of maternal and humoral immunity against Newcastle disease virus in chicken. International Journal of Poultry Science, 1, 161-163.

Sil, G. C., Das, P. M., Islam, M. R., \& Rahman, M. M. (2002). Management and disease problems of cockrels in some farms of Mymensingh, Bangladesh. International Journal of Poultry Science, 1, 102-105. 
Spradbrow, P. B. (1997). Policy framework for smallholder rural poultry development. In: Proceedings of International Workshop on Sustainable Poultry Production in Africa held in Addis Ababa, Ethiopia (pp. 30-39).

Tu, T. D., Phuc, K. V., Dinh, N. T. K., Quoc, D. N., \& Spradbrow, P. B. (1998). Vietnam trials with a thermostable Newcastle disease vaccine (strain $\mathrm{I}_{2}$ ) in experimental and village chickens. Preventive Veterinary Medicine, 34, 205-214.

Vui, T. Q., Lohr, J. E., Kyule, M. N., Zessin, K. Z., \& Baumann, M. P. O. (2002). Antibody levels against Newcastle disease virus, Infectious bursal disease virus and Influenza virus in rural chicks in Vietnam. International Journal of Poultry Science, 1, 127-132.

Table 1. Distribution of HI titers against NDV in serum samples of broiler chickens

\begin{tabular}{cccccccccccc}
\hline \multirow{2}{*}{$\begin{array}{c}\text { Age } \\
\text { (weeks) }\end{array}$} & $\begin{array}{c}\text { No. of } \\
\text { samples }\end{array}$ & \multicolumn{8}{c}{ Antibody titers obtained by HI test } & $\chi^{2}$ \\
\cline { 3 - 11 } & & $2^{1}$ & $2^{2}$ & $2^{3}$ & $2^{4}$ & $2^{5}$ & $2^{6}$ & $2^{7}$ & $2^{8}$ & GMT & $23.69^{*}$ \\
\hline $1-2$ & 191 & 17 & 37 & 22 & 43 & 59 & 13 & - & - & 12.78 \\
$3-4$ & 172 & - & 25 & 31 & 67 & 36 & 11 & 2 & - & 7.47 \\
$5-6$ & 147 & - & 33 & 49 & 30 & 17 & 13 & 3 & 2 & 5.67 \\
\hline
\end{tabular}

* Indicates significant at $\mathrm{p}<0.05$

Table 2. Distribution of HI titers against NDV in serum samples of layer chickens

\begin{tabular}{|c|c|c|c|c|c|c|c|c|c|c|c|c|c|}
\hline \multirow{2}{*}{$\begin{array}{c}\text { Age } \\
\text { (weeks) }\end{array}$} & \multirow{2}{*}{$\begin{array}{c}\text { No. of } \\
\text { samples }\end{array}$} & \multicolumn{11}{|c|}{ Antibody titers obtained by $\mathrm{HI}$ test } & \multirow{2}{*}{$\frac{\chi^{2}}{48.60 *}$} \\
\hline & & $2^{1}$ & $2^{2}$ & $2^{3}$ & $2^{4}$ & $2^{5}$ & $2^{6}$ & $2^{7}$ & $2^{8}$ & $2^{9}$ & $2^{10}$ & GMT & \\
\hline $17-28$ & 102 & - & 5 & 7 & 9 & 10 & 24 & 21 & 25 & 1 & & 33.11 & \\
\hline $29-40$ & 98 & - & 3 & 5 & 7 & 12 & 14 & 42 & 13 & 2 & & 37.13 & \\
\hline $41-52$ & 87 & - & 3 & 4 & 6 & 8 & 21 & 23 & 20 & 2 & & 39.05 & \\
\hline $53-64$ & 83 & - & 2 & 5 & 5 & 7 & 18 & 27 & 14 & 3 & 2 & 41.80 & \\
\hline 65 -above & 80 & - & 2 & 4 & 3 & 5 & 26 & 19 & 15 & 3 & 3 & 44.86 & \\
\hline
\end{tabular}

* Indicates significant at $\mathrm{p}<0.05$

Table 3. Distribution of HI titers against NDV in broiler and layer chickens in relation to seasons

\begin{tabular}{|c|c|c|c|c|c|c|c|c|}
\hline \multirow[t]{2}{*}{ Seasons } & \multicolumn{3}{|c|}{ Broiler } & \multirow[t]{2}{*}{$\chi^{2}$} & \multicolumn{3}{|c|}{ Layer } & \multirow[t]{2}{*}{$\chi^{2}$} \\
\hline & $\begin{array}{c}\text { No. of } \\
\text { samples }\end{array}$ & $<2^{3}$ & $\geq 2^{3}$ & & $\begin{array}{c}\text { No. of } \\
\text { samples }\end{array}$ & $<2^{3}$ & $\geq 2^{3}$ & \\
\hline $\begin{array}{c}\text { Summer } \\
\text { (Mar-May) }\end{array}$ & 140 & 14 & 126 & $7.81 *$ & 121 & 2 & 119 & $3.84^{*}$ \\
\hline $\begin{array}{c}\text { Rainy } \\
\text { (Jun-Aug) }\end{array}$ & 115 & 41 & 74 & & 112 & 8 & 104 & \\
\hline $\begin{array}{c}\text { Autumn } \\
\text { (Sep-Nov) }\end{array}$ & 131 & 27 & 104 & & 118 & 3 & 115 & \\
\hline $\begin{array}{c}\text { Winter } \\
\text { (Dec-Feb) }\end{array}$ & 124 & 30 & 94 & & 99 & 2 & 97 & \\
\hline
\end{tabular}

* Indicates significant at $\mathrm{p}<0.05$ 